\title{
Downregulated luteolytic pathways in the transcriptome of early pregnancy bovine corpus luteum are mimicked by interferon- tau in vitro
}

Raghavendra Basavaraja', Jessica N. Drum², Jackson Sapuleni', Lonice Bibi ${ }^{1}$, Gilgi Friedlander ${ }^{3}$, Sai Kumar ${ }^{1}$, Roberto Sartori ${ }^{2}$ and Rina Meidan ${ }^{*}$

\begin{abstract}
Background: Maintenance of the corpus luteum (CL) beyond the time of luteolysis is essential for establishing pregnancy. Identifying the distinct features of early pregnancy $C L$ remains unresolved, hence we analyzed here the transcriptome of $C L$ on day 18 pregnant (P) and non-pregnant (NP) cows using RNA-Seq. CL of P cows expressed ISGs, verifying exposure to the pregnancy recognition signal, interferon-tau (IFNT), whereas the CL of NP cows had elevated luteal progesterone levels, implying that luteolysis had not yet commenced.

Results: The DEGs, IPA, and metascape canonical pathways, along with GSEA analysis, differed markedly in the CL of P cows from those of NP cows, at the same day of the cycle. Both metascape and IPA identified similar significantly enriched pathways such as interferon alpha/beta, sonic hedgehog pathway, TNFA, EDN1, TGFB1, and PDGF. However, type-1 interferon and sonic hedgehog pathways were positively enriched whereas most of the enriched pathways were downregulated in the P compared to NP samples. Thirty-four \% of these pathways are known to be elevated by PGF2A during luteolysis. Notably, selective DEGs in luteinized granulosa cells were modulated by IFNT in vitro in a similar manner to their regulation in the $C L$ of $P$ cows.

Conclusion: This study unraveled the unique transcriptomic signature of the IFNT-exposed, early pregnancy CL, highlighting the abundance of downregulated pathways known to be otherwise induced during luteolysis. These and IFNT-regulated in vitro pregnancy-specific DEGs suggest that IFNT contributes to the characteristics and maintenance of early pregnancy $\mathrm{CL}$.
\end{abstract}

Keywords: RNA seq, Maternal pregnancy recognition, Prostaglandin F2 alpha, Luteinized granulosa cell

\section{Background}

In mammalian species including cattle, a corpus luteum (CL) that produces and secretes adequate amounts of progesterone is critically important for reproductive success $[1-3]$. Indeed, there is a direct relationship between

\footnotetext{
* Correspondence: rina.meidan@mail.huji.ac.il

1 Department of Animal Sciences, The Robert H. Smith Faculty of Agriculture, Food and Environment, The Hebrew University of Jerusalem, 7610001 Rehovot, Israel

Full list of author information is available at the end of the article
}

the concentrations of progesterone and embryonic survival during early pregnancy $[4,5]$. In the absence of an embryonic signal, uterine prostaglandin F2A (PGF2A) luteolytic pulses will cause CL regression [6, 7]. However, if fertilization occurs, the viable embryo will signal its presence so that the CL is maintained $[1,2]$. Interferon tau (IFNT) has been shown to be the definitive pregnancy recognition signal in ruminants $[8,9]$. It is structurally homologous to the other type- 1 interferons

(c) The Author(s). 2021 Open Access This article is licensed under a Creative Commons Attribution 4.0 International License, which permits use, sharing, adaptation, distribution and reproduction in any medium or format, as long as you give appropriate credit to the original author(s) and the source, provide a link to the Creative Commons licence, and indicate if changes were made. The images or other third party material in this article are included in the article's Creative Commons licence, unless indicated otherwise in a credit line to the material. If material is not included in the article's Creative Commons licence and your intended use is not permitted by statutory regulation or exceeds the permitted use, you will need to obtain permission directly from the copyright holder. To view a copy of this licence, visit http://creativecommons.org/licenses/by/4.0/ The Creative Commons Public Domain Dedication waiver (http://creativecommons.org/publicdomain/zero/1.0/) applies to the data made available in this article, unless otherwise stated in a credit line to the data. 
such as interferon alpha (IFNA) and interferon beta (IFNB). All of them act through the classical type-1 interferon pathway and stimulate the Interferonstimulated genes (ISGs) in the endometrium [10-13]. These ISGs include the interferon regulatory factors (IRFs) family, ISG15, MX1 (MX Dynamin Like GTPase 1), MX2, 2'-5'-Oligoadenylate Synthetase 1 (OAS1Y), and signal transducer and activator of transcription (STATs) [14-18]. IFNT in cows is produced by the trophoblastic cells throughout days 7-28 after insemination $[8,19,20]$, with peak production on days $18-20$ [19]. There is ample evidence that IFNT acts in the endometrium to inhibit uterine pulses of PGF2A $[8,9$, $21,22]$ during maternal recognition of pregnancy. Nevertheless, in addition to its uterine actions, an endocrine role for IFNT has been suggested $[9,23]$. Antiviral activity was detected in uterine vein blood [14, 24] and ISGs were expressed in CL from pregnant ruminants as well as during uterine vein infusion of recombinant ovine IFNT (roIFNT) [14, 17, 18, 25]. Notably, endocrine delivery of roIFNT, via the uterine or jugular vein, protected the ovine $\mathrm{CL}$ from the luteolytic actions of PGF2A [26]. Furthermore, intraluteal and circulating progesterone levels as well as CL volume were maintained, and these CL had a greater expression of genes for cell survival [26]. Our in vitro data, which show the effects of IFNT on luteal cells [16, 17, 27], further support a direct role of IFNT on luteal function.

How CL in distinct physiological states differ (i.e., cyclic, regressed, and pregnancy $\mathrm{CL}$ ), remains an intriguing question. Specifically, it is unclear whether the distinct features of early pregnancy $C L$ are due to reduced PGF2A, the endocrine action of IFNT, or other yet unknown factors.

Several transcriptomic studies of early pregnant ruminant CL have been conducted in recent years $[15$, 28-30]. These studies reported genes and pathways that are specific for pregnancy. However, despite the wealth of information provided, there was little overlap of the differentially expressed genes (DEGs) and the regulated pathways in these studies. Most probably due to the different reference group, which were cyclic, pregnant at different stages, or regressing CL $[15,28-30]$. Here we analyzed the transcriptome of day matched (day 18) CL of pregnant (P) and nonpregnant (NP) cows. Our data show that the CL of $\mathrm{P}$ cows expressed ISGs, suggesting an exposure to IFNT, whereas the CL of NP cows had elevated luteal progesterone levels, implying that they had not yet begun luteolysis. Therefore, a comparison of these CL provides unique physiological model to uncover luteal effects conferred by IFNT. To gain further understanding of IFNT actions, selective DEGs identified in the transcriptomic analysis were determined in luteinized granulosa cells (LGCs) incubated in vitro with roIFNT.

\section{Results}

Transcriptomic comparison of day $18 \mathrm{CL}$ pregnant $(\mathrm{P})$ and non-pregnant (NP) cows

Prior to tissue collection, pregnancy was confirmed by the presence of an embryo in uterine flushes on the day of slaughter. Luteal progesterone concentrations did not differ between the P and NP cows $(P=746 \pm 6.7 \mathrm{pg} / \mathrm{ug}$ protein; $(n=6) ; \mathrm{NP}=635 \pm 190 \mathrm{pg} / \mathrm{ug}$ of protein $(\mathrm{n}=6)$, confirming that $\mathrm{CL}$ of NP group were not undergoing regression at the time of collection. RNA seq analysis using the NGS platform was carried out in order to identify the transcriptomic changes between day $18 \mathrm{CL}$ of the $\mathrm{P}$ and NP group. Initially principal component analysis (PCA) was used to assess the overall mRNA profile differences among the samples; it showed that the P and NP samples were clustered separately (Supplementary Figure 1). The hierarchical clustering was performed along with a dendrogram on top, which is drawn as shown in Fig. 1A. There was a similar expression pattern among the samples and a clear separation of NP from $P$ samples was observed. As shown in Fig. 1B, a volcano plot of differential abundance revealed that there were 3437 DEGs between $\mathrm{P}$ compared to NP. Among the 3437 DEGs, 1872 (54\%) genes were downregulated, whereas 1565 (46\%) genes were upregulated when comparing P and NP (Supplementary Figure 1). For validation of DEGs in RNA seq by qPCR, ten DEGs (ISG15, MX2, PDGFB, GLI family zinc finger 1 (GLI1), GLI2, HPGD, TIMP3, ADAM17, THBS2, and STAT1) were selected. RNA samples from the same samples assigned to the RNA-Seq analysis $(n=6$ for either $\mathrm{P}$ or $\mathrm{NP}$ ) were used for the qPCR validation. The pattern of expression observed by qPCR was similar to the RNA seq analysis except for STAT1, as depicted in Fig. 1C.

\section{Functional enrichment and pathway analysis}

To gain more insight into key processes that may explain the functional differences between the P and NP group, functional annotation analyses were carried out using IPA and metascape. Both metascape and IPA identified 14 common, significantly enriched pathways such as interferon alpha/beta, sonic hedgehog $(\mathrm{SHH})$, tumor necrosis factor receptor 2 (TNFR2), EDN1, TGFB1, and thrombin (Fig. 2A). Figure 2B presents selective downregulated pathways with a significant inactivation score (Z-score) and padj $\leq 0.05$ in IPA analysis. Most of the enriched pathways were downregulated in the $\mathrm{P}$ compared to NP samples. Then by analyzing the linkage to DEGs through coordinated expression, we identified, using IPA tool, potential upstream regulators [31]. These predictions are based on the literature compiled in the Ingenuity pathway knowledge base. The top upstream regulators (both 


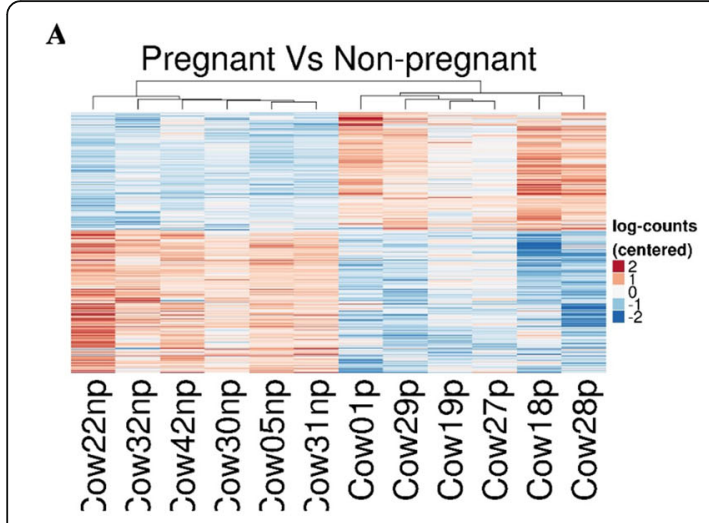

B.

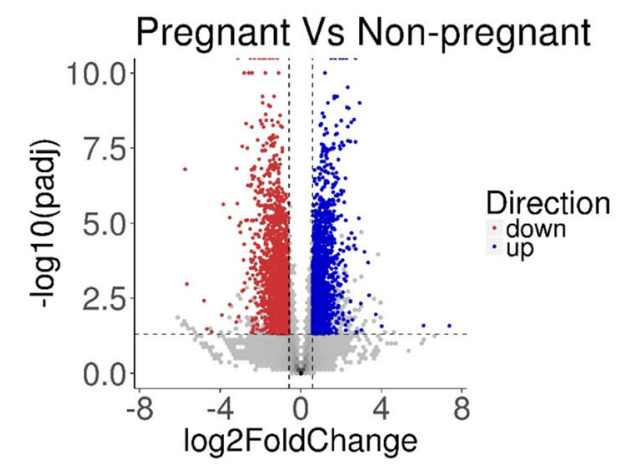

C.
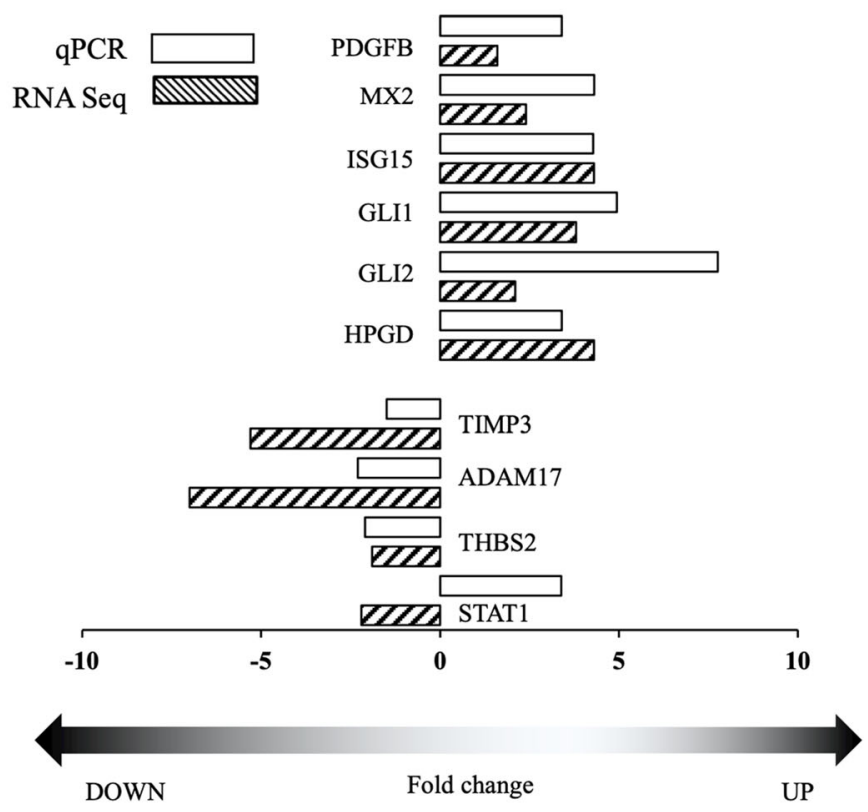

Fig. 1 Global changes of DEGs in day 18 P compared to NP bovine CL. (A) A total of 3437 genes were significantly differentially expressed between the $\mathrm{CL}$ of $\mathrm{P}$ compared to NP samples. The log 2 normalized counts were centered to have for each gene a mean of zero. Hierarchical clustering of the centered values was performed with the Pearson dissimilarity measure. The expression profile is accompanied by a colored bar indicating the centered log 2 normalized counts. Hierarchical clustering of the centered values was performed with the Pearson dissimilarity measure. Each column represents an individual cow and each row represents a gene. (B) A volcano plot was constructed, satisfying the criteria of $-\log 2$ fold-change value $>0.58$ or $<-0.58$ and padj $<0.05$. The $x$-axis and $y$-axis in the volcano plot represent the $\log 2$ ratio and -log 10 (padj), respectively. Points are colored according to their average log ratio in the data set. Red and blue indicate that the expression level was decreased or increased, respectively. (C) Validation of selective DEGs with qPCR analysis where the fold change (P compared to NP) of RNA seq analyses (dark patterned bars) was compared with the GPCR results (open bars). Positive and negative values represent up- and down-regulated DEGs, respectively

activated and inactivated) in the P compared to the NP samples data set are listed in Fig. 3 (Z-score $\geq 2$ and $p a d \leq 0.05$ ). There is an apparent overlap in the regulatory actions of these regulators with the affected pathways, illustrated in Fig. $2 \mathrm{~A}$ and $\mathrm{B}$. Most of the activated upstream regulators include receptors and transcription factors associated with the interferon pathway (IFNAR1, IFNAR2, STAT2, IFNG, and IRF7; Fig. 3). Other activated upstream regulators were TNF, a pleiotropic cytokine and STAT2 that mediates signaling by type I IFNs. The inhibited set of upstream regulators list included ESR1, TGFB1, FSH, ARNT, HIF1A, and others, depicted in Fig. 3.

Type-1 interferon and sonic hedgehog pathways are positively enriched in the day $18 \mathrm{CL}$ of $\mathrm{P}$ compared to NP cows

We also used Gene Set Enrichment Analysis (GSEA) to identify potential pathways that are modified in the early pregnancy CL. GSEA within MSigDB using a stringent false discovery rate $(F D R)$ cutoff $(F D R<0.05)$ revealed the enrichment of several pathways in the $\mathrm{P}$ compared to NP samples. Among them, there was an enrichment of type-1 interferon pathway genes in the $\mathrm{P}$ group compared to the NP group (normalized enrichment signal (NES) $=1.92$ and false discovery rate $(\mathrm{FDR})=0.034$, Fig. $4 \mathrm{~A})$. The key genes, included in the list are $M X 1, I S G 15, O A S 1, M X 2$, IRF9, IRF3, and other type- 1 interferon-related genes. This analysis is in agreement with data shown in Fig. 2A and 3. Furthermore, IPA network analysis also showed that type1 interferon pathways were significantly enriched ( $p a d j=$ 0.003 ) with genes including ISG15, OAS1,MX1, GIP2, GIP3, and IRF9 (Fig. 4B). Some of these ISGs (IRF9, $I S G 15, M X 2$, and $O A S 1$ ) were previously shown to be significantly elevated by in vitro treatment of roIFNT in bovine CL tissue, luteal endothelial cells, and LGCs $[16,17]$ (Insert table Fig. 4B). 
A.

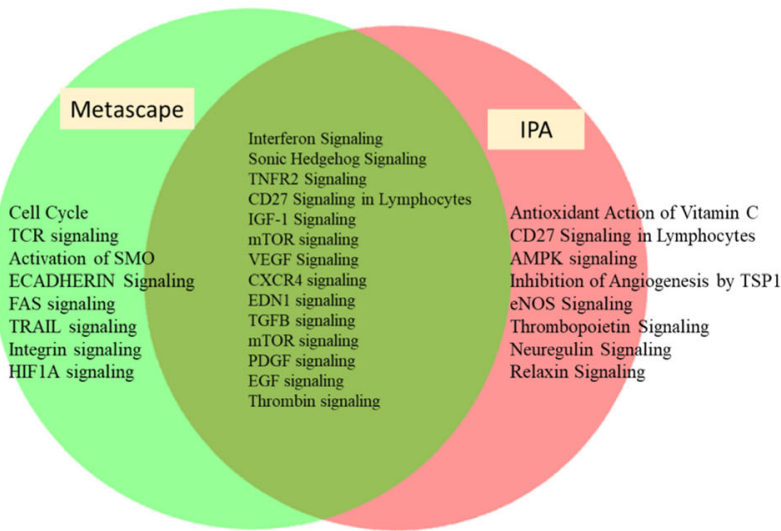

B.

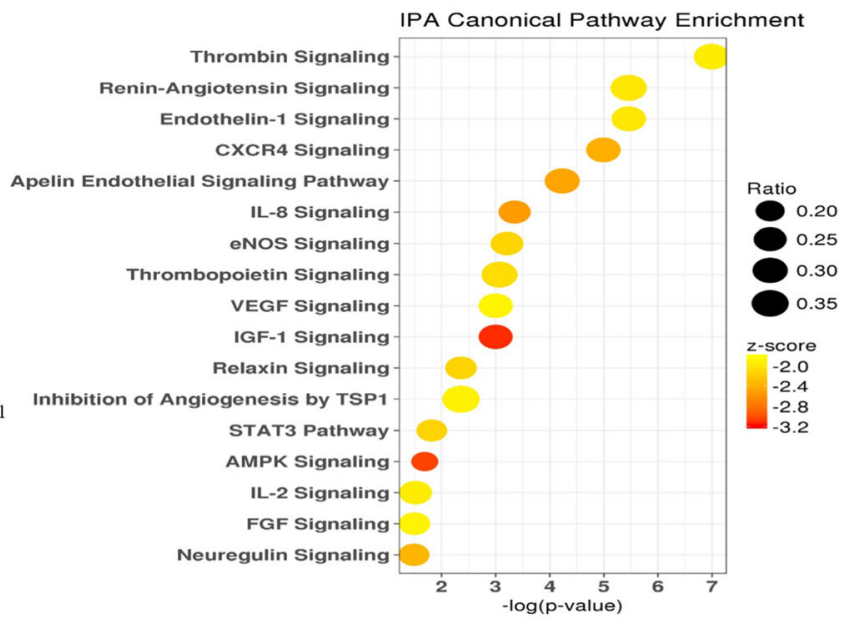

Fig. 2 Functional pathway enrichment of DEGs in day 18 P compared to NP bovine CL. (A) Pathway enrichment analysis was performed using Metascape and IPA on both up- and downregulated DEGs. The significantly (padj < 0.05) enriched canonical pathways in both tools are represented in a Venn diagram. (B) A dot plot of selected significantly enriched pathways from IPA analysis that were down-regulated in P compared to NP (padj< 0.05; Z-score <-1.9). The x-axis represents the -log padj. The color indicates the Z-score (a Z-score below - 2 indicates that the pathway is significantly downregulated). The size of the dots represents the gene ratio (the number of genes in the pathway that were significantly differentially expressed relative to the number of genes in the pathway)

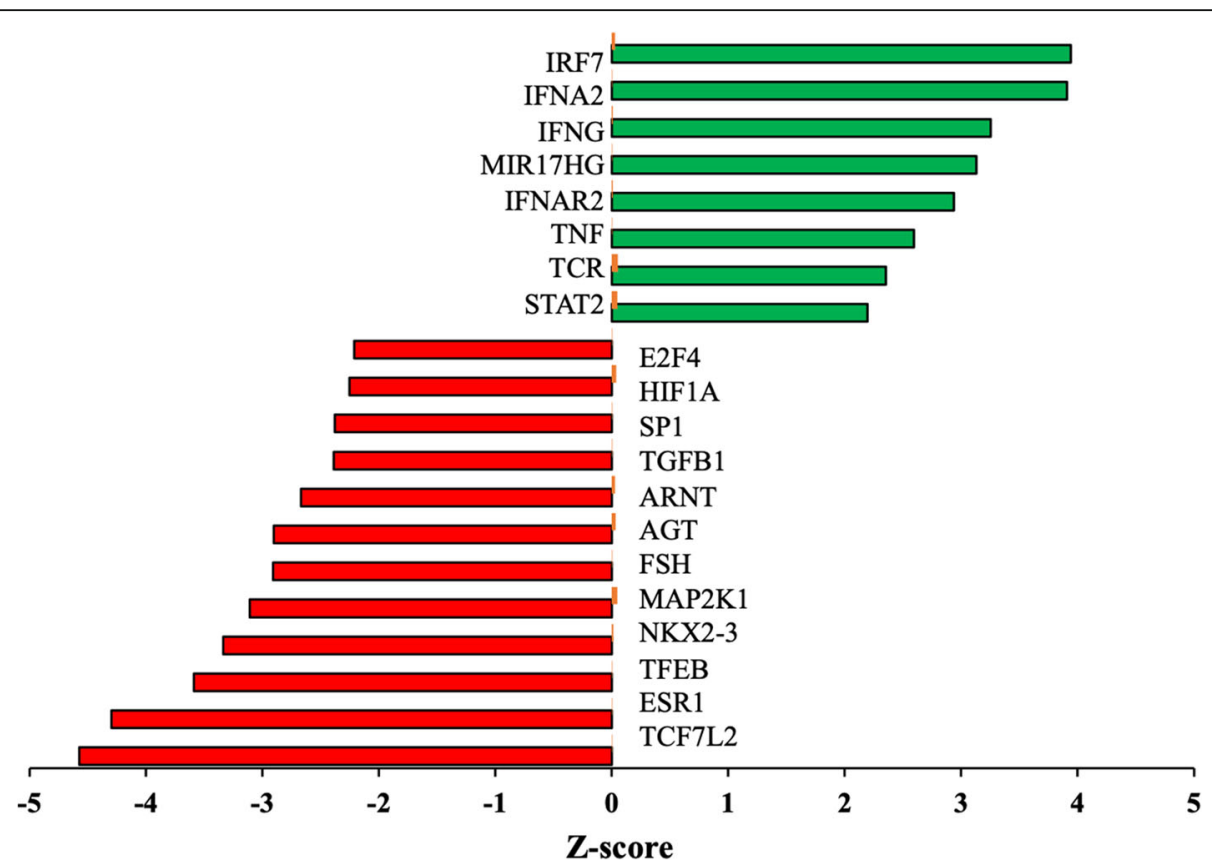

Fig. 3 Upstream regulators for DEGs in bovine CL from day 18 P and NP cows. Bar graphs show the top activated and inhibited upstream regulators in day $18 \mathrm{P}$ cows compared to NP cows predicted by IPA analysis (default cut off Z-score $>2$ or $<-2$ and padj $<0.05$ ). Green bars indicate the activated upstream regulators and the red bars indicate the upstream-inhibited regulators. The $x$-axis represents the Z-score 


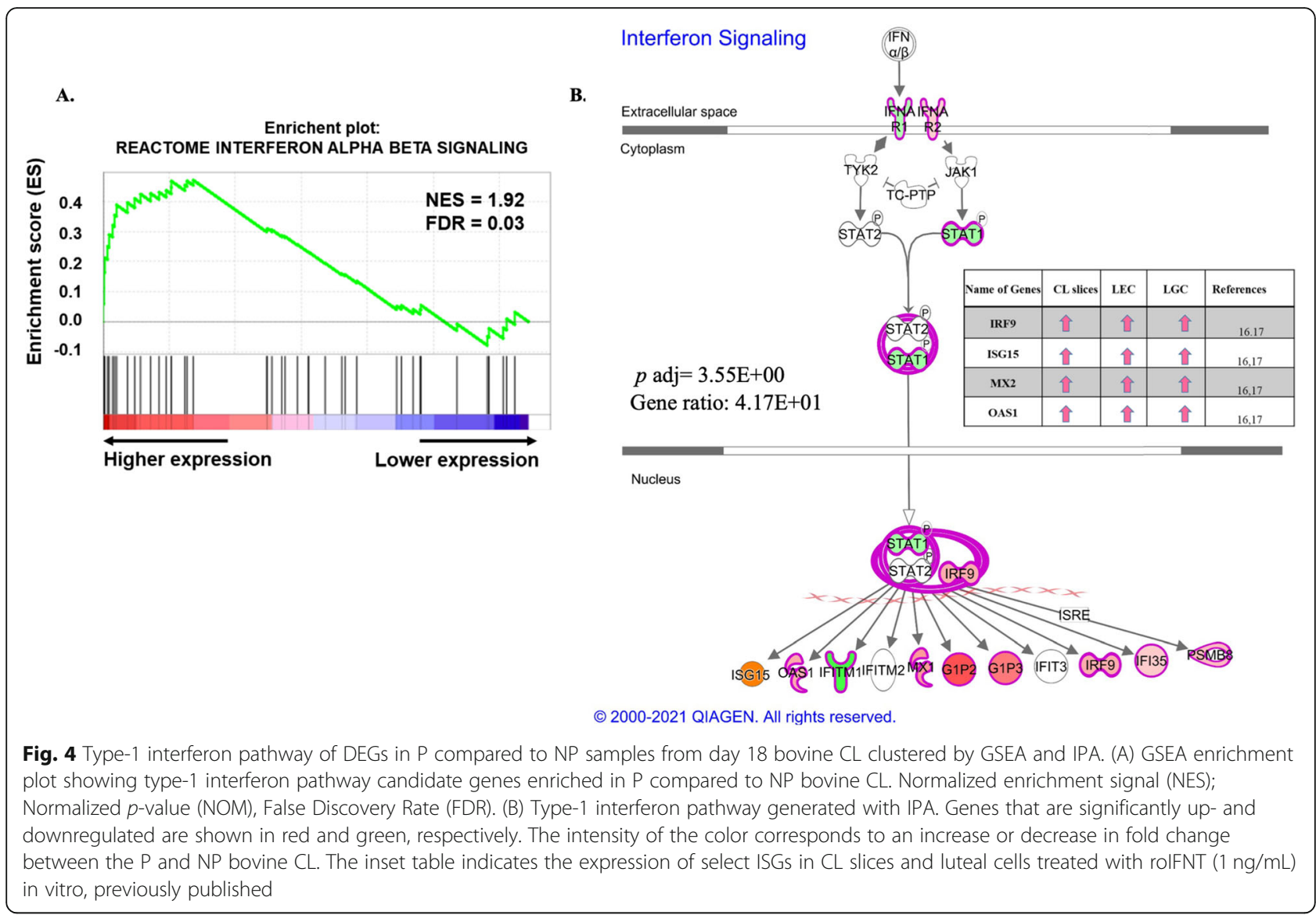

Sonic hedgehog is one of the few prominent pathways that were significantly activated in P compared to NP samples in both the metascape and IPA analysis. Differentially regulated candidate genes, along with their pathways exported from IPA, are shown in Fig. 5A. Among the candidate genes, GLI1, GLI2, and PTCH2 were significantly upregulated in the P compared to NP samples. Inhibitors of the SHH pathway such as the SUFU and PKA family were negatively regulated in the $\mathrm{P}$ compared to NP samples (Fig. 5A). To assess the effect of in vitro roIFNT treatment on this pathway, LGCs were cultured for $24 \mathrm{~h}$ with $1 \mathrm{ng} / \mathrm{mL}$ of roIFNT. As shown in Fig. 5B, roIFNT significantly upregulated GLI2 and PTCH2 without affecting GLI1 and SUFU expression.

\section{Pregnancy negatively enriched TGFB and matrix metalloproteinase pathways in day $18 \mathrm{CL}$}

The IPA analysis revealed that candidate genes related to the TGFB pathway were significantly regulated, as illustrated by a heat map in Fig. 6A. Within this group of DEGs, a subset of 13 genes was significantly downregulated including TGFBR1, TGFBR2 and their signaling molecules, SMAD2 and SMAD3 (Fig. 6A), whereas 9 genes were upregulated in the $\mathrm{P}$ compared to NP samples. This list included BMP4, ERAS, INHBA, and others.
Similarly, to $\mathrm{P}$ cows, the in vitro results show that roIFNT inhibited markedly, by almost half, the expression of the two TGFB1 receptors, TGFBR1 and TGFBR2, compared with the control (Fig. 6B). However, contrary to $\mathrm{P}$ cows, roIFNT significantly downregulated the expression of BMP4 in LGCs (Fig. 6B).

As shown in Fig. 7A, GSEA analysis revealed that the activation of the matrix metalloproteinase (MMP) pathway is negatively enriched in $\mathrm{P}$ compared to NP cows with NES $=-1.9$ and FDR $<0.033$. The genes related to this pathway are also illustrated by a heat map, as depicted in Fig. 7B. To study whether some of the genes related to this pathway are affected by IFNT, we determined their expression in LGCs that were treated with roIFNT. The results indicated that THBS2, TIMP3, $A D A M 17$, and $M M P 9$ were all significantly downregulated at $24 \mathrm{~h}$ incubation expect $M M P 9$ which required a longer incubation period (36 h; Fig. 7C).

Among the DEGs, we noted that genes associated with prostaglandin response and metabolism, e.g., 5Hydroxyprostaglandin Dehydrogenase (HPGD), Prostaglandin-endoperoxide synthase (PTGS2), and the oxidoreductase family gene, CBR3, were positively regulated in the $\mathrm{P}$ compared to NP samples as depicted in Fig. 8A heatmap. Whereas the PGF2A receptor, PTGFR, 
A

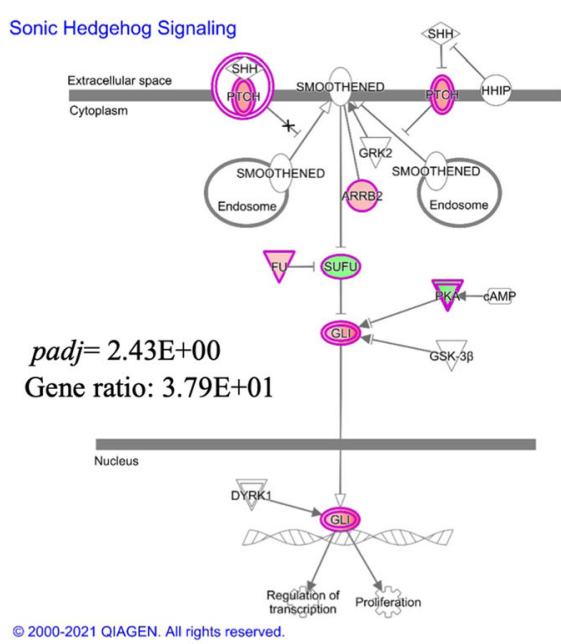

B.
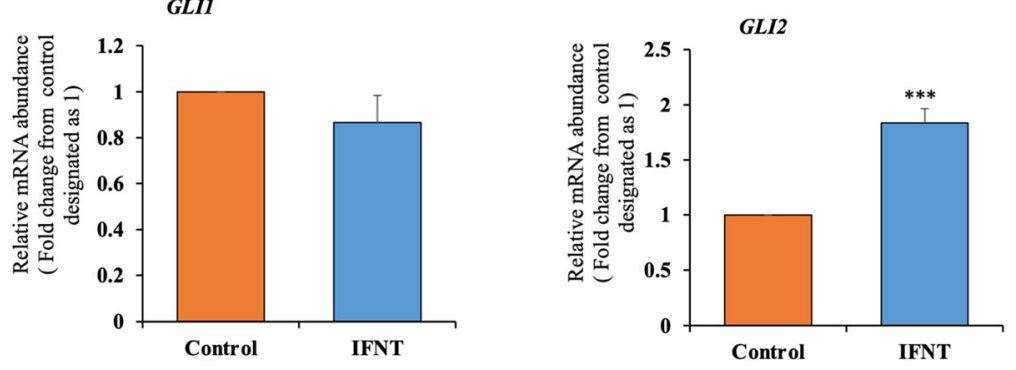

24h incubation
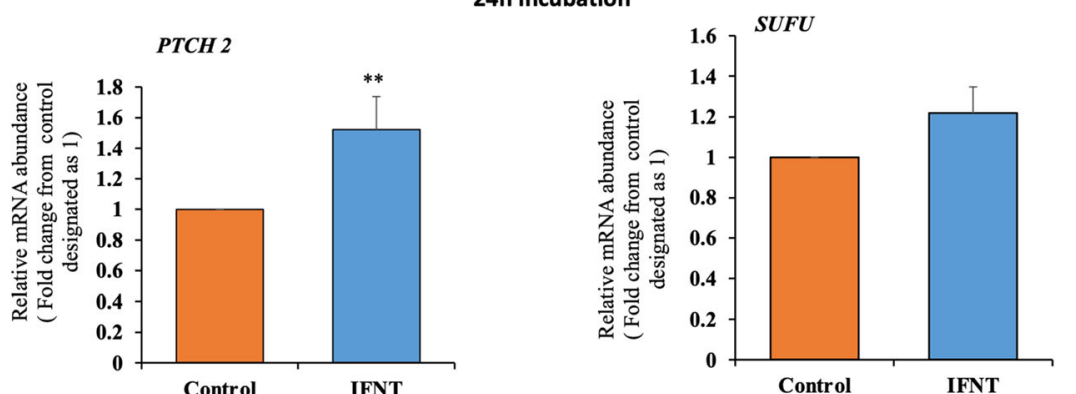

Fig. 5 Sonic hedgehog pathway in bovine CL and LGCs. (A) Sonic hedgehog pathway from IPA, genes that are significantly up- and downregulated are shown in red and green, respectively. The intensity of red and green colors corresponds to an increase or decrease in fold change levels of P compared to NP bovine $\mathrm{CL}$, respectively (B) LGCs $(n=5)$ were treated with either basal media (control) or rolFNT (1 ng/mL) for $24 \mathrm{~h}$. GLI1, GLI2, PTCH2, and SUFU mRNA expression were measured by qPCR. Asterisks denote significant differences from their controls $\left(*^{* *} p<0.01\right.$ and $\left.^{* * *} p<0.001\right)$

A.

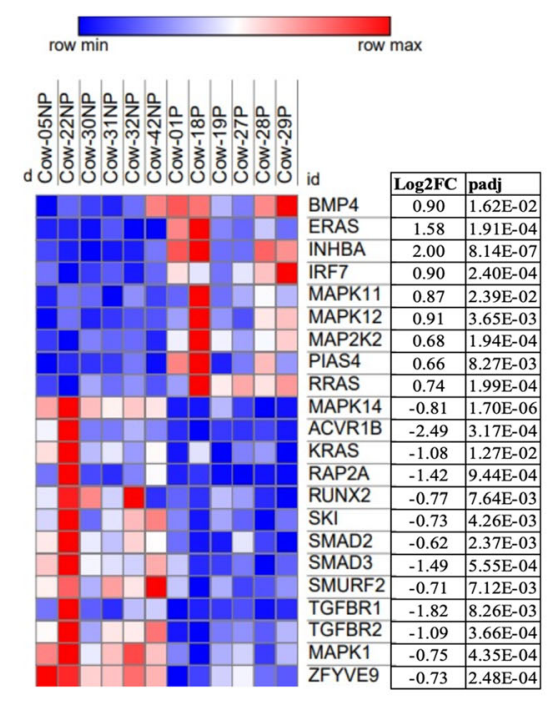

B.
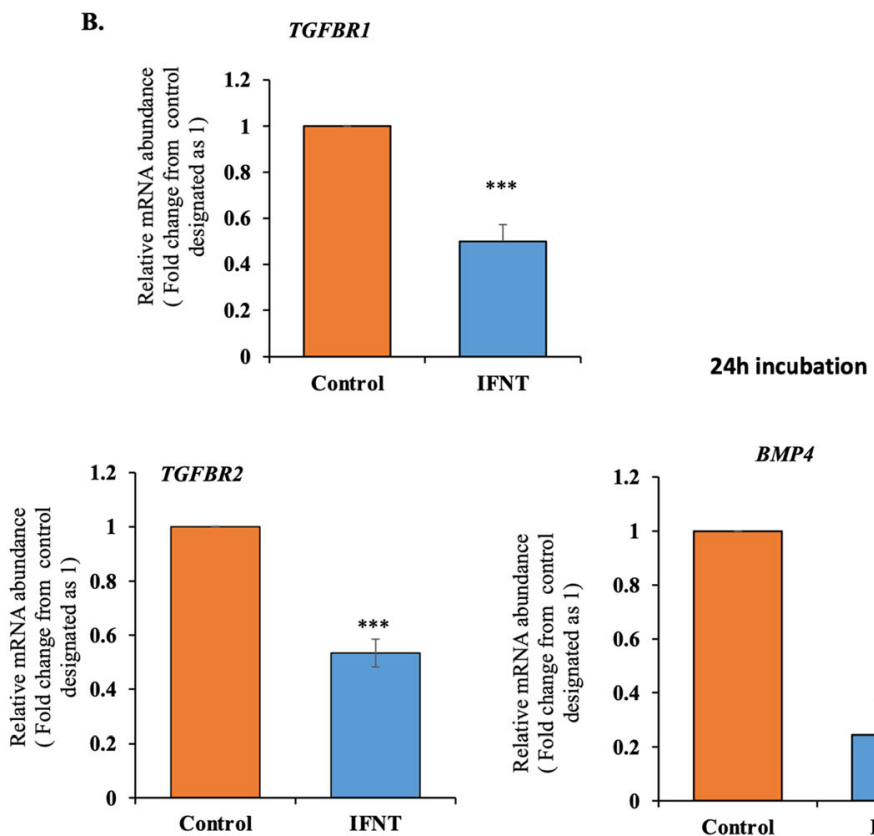

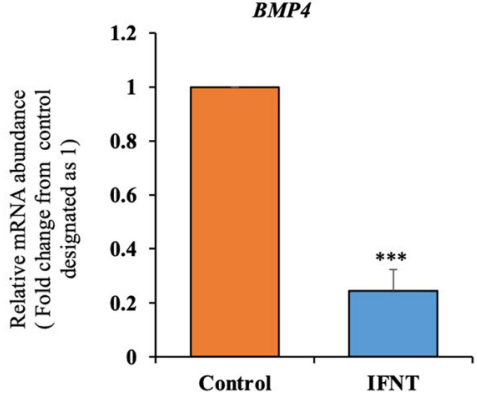

Fig. 6 Analysis of the TGFB pathway in the P compared to NP bovine CL and the in vitro effect of IFNT in LGCs. (A) Heatmap showing differentially abundant TGFB pathway candidate genes. The heatmap was generated by Morpheus - Broad Institute (https://software. broadinstitute.org/morpheus/). Higher and lower levels of DEGs are denoted in red and blue, respectively, and the median level is denoted in white. The intensity of color corresponds to an increase or decrease in the fold change of the particular DEG. (B) LGCs $(n=4)$ were treated with either basal media (control) or rolFNT (1 ng/mL) for $24 \mathrm{~h}$. TGFBR1, TGFBR2 and BMP4 expression were measured by qPCR. Asterisks denote significant differences from their controls $\left({ }^{* *} p<0.001\right)$ 
A.

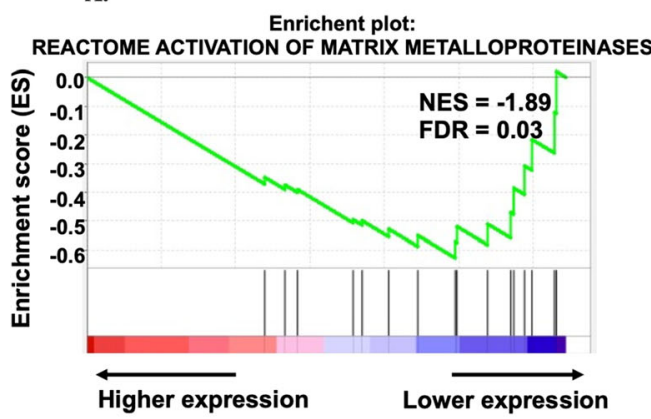

B.

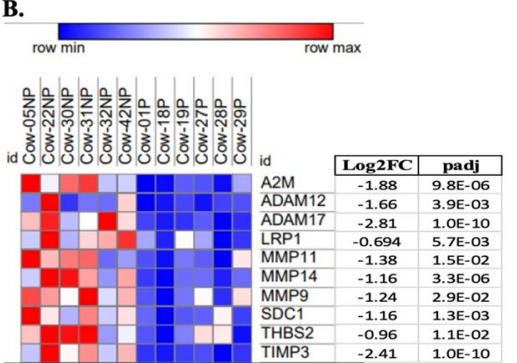

C.
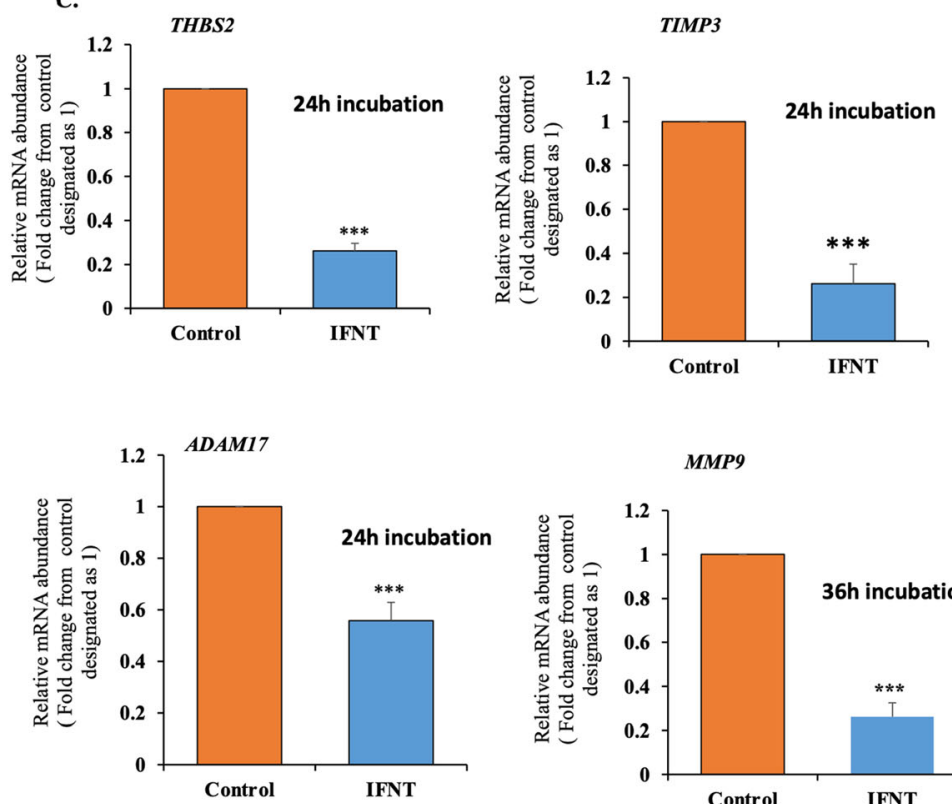

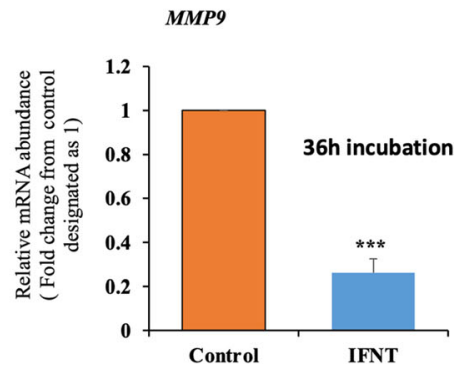

Fig. 7 Matrix metalloproteinases pathway in P compared to NP of day 18 bovine CL and the in vitro effect of IFNT in LGCs. (A) GSEA results showing the activation of matrix metalloproteinase candidate genes enriched in day 18 P compared to NP bovine CL. (B) Heatmap showing the differentially abundant activation of matrix metalloproteinase candidate genes. The heat map was generated by Morpheus - Broad Institute (https://software.broadinstitute.org/morpheus/). Higher and lower levels of transcript accumulation are denoted in red and blue, respectively, and the median level is denoted in white. (C) LGCs $(n=5)$ were treated with either basal media (control) or rolFNT $(1 \mathrm{ng} / \mathrm{mL})$ for $24 \mathrm{~h}$ for all except MMP9, which was for $36 \mathrm{~h}$. THBS2, TIMP3, ADAM17, and MMP9 expression was measured by qPCR. Asterisks denote significant differences between rolFNT treatment and controls $(* * * p<0.001)$

the receptor inhibitor, PTGFRN, its transporter, $A B C C 9$, and others were negatively regulated in $\mathrm{P}$ compared to NP samples (Fig. 8A heatmap). In LGCs, roIFNT mimicked some of these effects, for instance, the expression of HPGD ( 1.3-fold), and PTGS2 ( 8-fold) were elevated, whereas PTGFR was downregulated, as shown in Fig. 8B.

The IPA diseases and biological functions tool identified several networks associated with cellular and molecular functions, which include cell death and survival, cellular function and maintenance, cellular proliferation and survival, cellular movement as well as the cell cycle (Fig. 9A). Further analyses utilizing GSEA GO terms, which incorporate the directionality of gene changes between groups, revealed positive enrichment of cell cycle of G2-M transition in P compared to NP groups (Fig. 9B).

\section{Discussion}

This study utilized various functional annotation tools to analyze the transcriptome of bovine $\mathrm{CL}$, dissecting the molecular profile of $\mathrm{d} 18 \mathrm{P}$ cows for the first time and demonstrating that it is strikingly different from that of non-luteolytic, NP CL at the same day of the cycle. This conclusion is based on DEGs, IPA, and metascape canonical pathways, GSEA enrichment plots, along with molecular and cellular functions. Unlike previous publications, this study captured the transcriptome of early pregnancy CL exposed to IFNT and compared it to nonluteolytic cyclic CL, thus singling out the effects of IFNT [15, 28-30].

Several findings here indicate that the $\mathrm{CL}$ of $\mathrm{P}$ cows were exposed to IFNT, including the enrichment of the IFNA/B signaling pathway, IFN and its receptors were identified as an upstream regulators along with various ISGs differentially expressed in the $\mathrm{P}$ compared to NP analysis. An outstanding finding of this study was that most IPA canonical pathways were downregulated in $\mathrm{P}$ cows, whereas very few pathways were upregulated. Importantly, the selective DEGs studied here in LGCs, were regulated by roIFNT in vitro similarly to their regulation in the $\mathrm{CL}$ of $\mathrm{P}$ cows, supporting the notion that IFNT affects luteal gene expression in vivo. This is further corroborated by previous findings demonstrating that various ISGs (IRF9, ISG15, MX2, and OAS1) were elevated by roIFNT treatment in vitro of in various luteal cell models [16-18, 32, 33].

Many of the downregulated pathways in the pregnancy $\mathrm{CL}$ were pathways whose involvement in luteal 


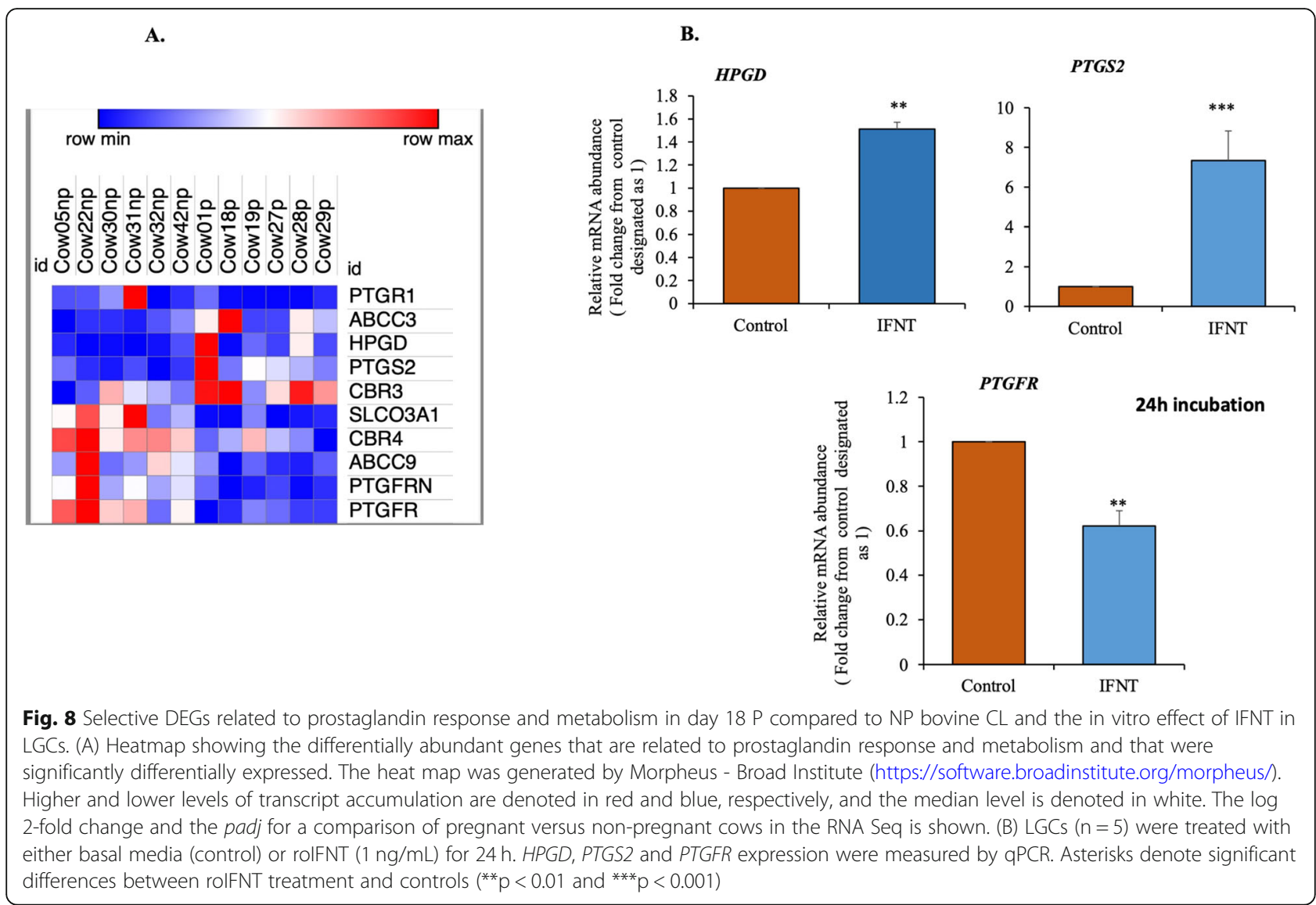

regression was established before. Among them EDN1, eNOS, CXCR4, VEGF, IL8, TGFB1, THBS1, IGF1, STAT3, and FGF2 signaling [15, 16, 34-38]. Moreover, most of these pathways were previously shown to be induced by PGF2A specifically in the responsive gland [7, $35,38,39]$. The suppression of the luteolytic pathway in the pregnancy CL suggested by our findings imply that at this initial phase of pregnancy the gland can resist PGF2A luteolytic actions. Our results provide an explanation why in ruminants ample evidence showed that the $\mathrm{CL}$ of early pregnancy is more resistant to the luteolytic action of PGF2A [40-46].

The issue of whether and how PGF2A secretion differs in the pregnant compared the cyclic cow or ewe is controversial. On the one hand, pregnant ruminants were reported to have higher concentrations of basal PGF2A than cyclic animals have $[47,48]$. However, recent publications have suggested that although the numbers of PGF2A pulses per day were significantly higher during luteolysis, compared with pregnant animals, they were similar in the pregnant animals and in those at the late luteal phase $[40,49]$. Additionally, PGF2A can reach the $\mathrm{CL}$ during early pregnancy as shown by Banu and coworkers [50].
TGFB1 signaling is a pathway that was shown to be significantly enriched and repressed in the current study in $\mathrm{P}$ compared to NP cows, as well as in previous reports [15, 28] (see Figs. 2, 3, and 6). TGFB1 is extensively studied in relation to luteolysis and was shown to be specifically upregulated by PGF2A in the mature CL [34, 51]. Functionally, TGFB1 promotes apoptosis of bovine luteal endothelial cells [51-53], limits their cell growth, and disrupts capillary morphogenesis and endothelial barrier function [53]. Previously we reported that IFNT inhibits TGFB1 expression in luteal endothelial cells and CL slices [16], here we observed that TGFBR1 and TGFBR2 were inhibited in vitro by IFNT in LGCs, suggesting a multicellular, effective shutdown of TGFB1 signaling in the pregnancy CL.

Downregulation of TGFB1 signaling in the CL of $\mathrm{P}$ cows would preserve the structure and function of luteal vasculature. Similarly, inhibition of THBS1 proapoptotic and antiangiogenic activities $[51,54]$ during pregnancy is expected to support luteal blood vessel integrity. Another factor that may take part in vascular maturation is PDGFB, which attracts pericytes, thus stabilizing blood vessels [55]. This study demonstrated that PDGFB is upregulated in the $\mathrm{CL}$ of $\mathrm{P}$ cows and is stimulated by 


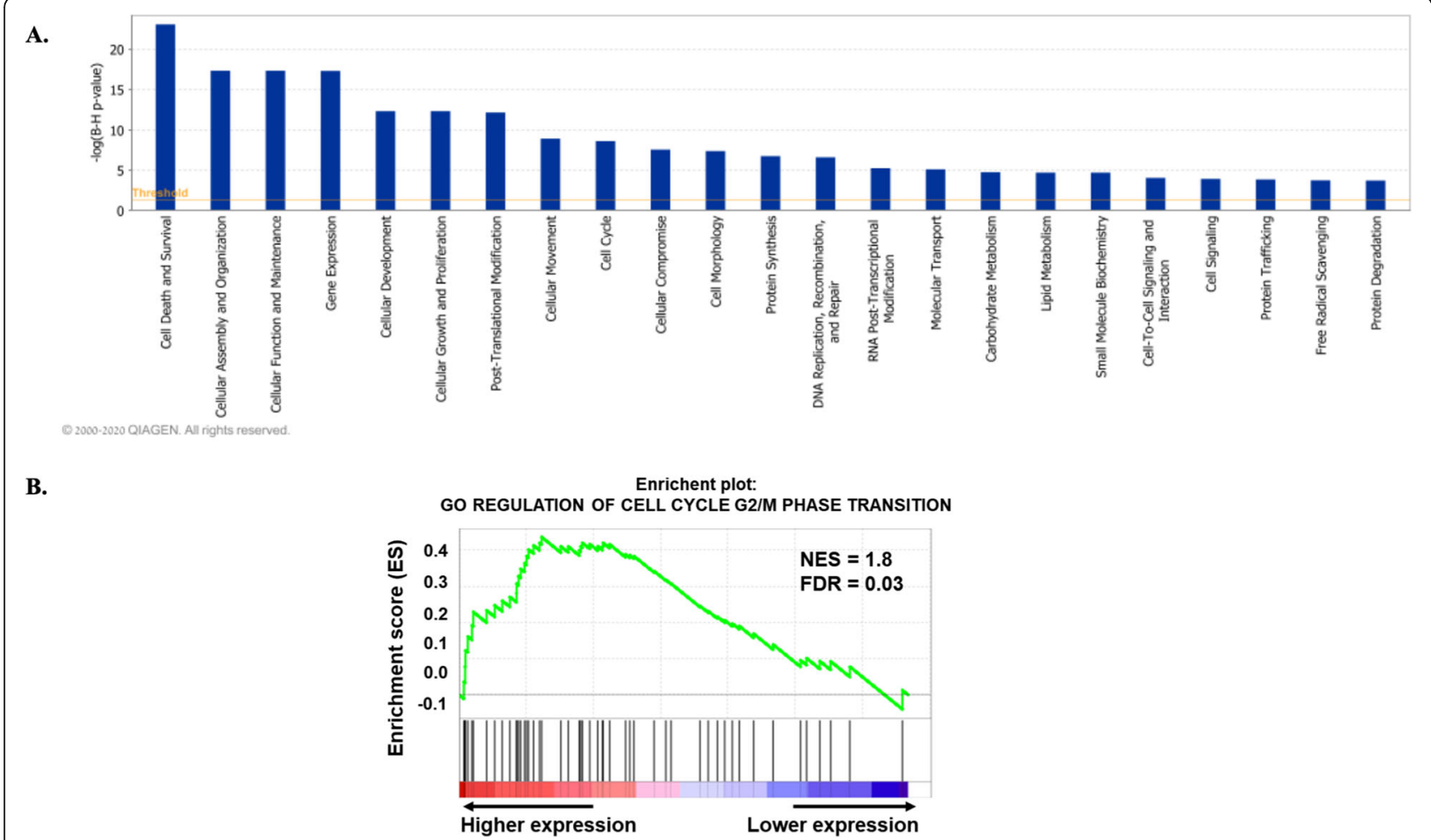

Fig. 9 Enrichment of biological functions related to cell cycle in P compared to NP day 18 bovine CL. A Bars indicate the likelihood [-log B-H ( $p$ value)] that the specific molecular and cellular functions obtained from IPA disease and biological functional categories analysis was affected by $P$ cows compared with NP cows. B GSEA enrichment plot of the Gene Ontology (GO) term regulation of the cell cycle G2/M transition

roIFNT in LGCs in vitro [17]. Corroborating this notion, in bovine luteal endothelial cell network established in vitro, the inhibition of PDGF signaling markedly decreased its formation and sprouting [56]. Notably, FGF2 and VEGFA signaling, the principal mitogens of luteal angiogenesis, were found here to be reduced in early pregnancy, suggesting that there is no new wave of angiogenesis during CL maintenance. Indeed, staining of the endothelial cell marker von Willebrand factor did not change in corpora lutea from day 16 of the estrous cycle to day 40 of pregnancy and remained the same in day $16 \mathrm{P}$ compared to NP cows [55].

EDN1, a vasoactive peptide, was one of first compounds reported to be elevated by PGF2A in a temporal manner during luteolysis [57, 58]. Therefore, inhibition of EDN1 by pregnancy CL (the current study and [59, 60]) or by roIFNT in vitro [16] is expected to maintain dilated vessels that are likely to enable nutrient and hormone exchange. Besides its role as a vasoconstrictor, luteal EDN1 was shown to act as the local mediator of PGF2A in reducing progesterone output $[57,58]$. The same applies to renin-angiotensin signaling. Previous studies pointed out that angiotensin II (Ang II) release is stimulated by PGF2A and that Ang II decreases progesterone release [61]. Ang II also acts in synergism with EDN1 during luteolysis [61]. Notably, no major steroidogenic genes were differentially expressed in $\mathrm{P}$ cows here and in Romero's transcriptional analysis of pregnant sheep CL [15]; nevertheless, reduced EDN1 and Ang II can help maintain progesterone output during early pregnancy.

In addition to genes that form luteolytic signature (TGFB1, THBS1, EDN1, and NOS3), several genes related to prostaglandin metabolism were differentially expressed in pregnancy $\mathrm{CL}$ and modulated in vitro by roIFNT. Among those genes related to prostaglandins, PTGS2 and HPGD were upregulated and PTGFR was downregulated. Such regulation may imply reduced response to PGF2A and enhanced prostaglandin synthesis during pregnancy most probably PGE2, shown to play luteoprotective role [62, 63].

The current study also unearthed a novel pathway, one of the few upregulated $(\mathrm{Z}$-score $=3.162 ; \mathrm{padj}=0.002$ ) in early pregnancy $\mathrm{CL}$, known as the SHH pathway. It is a highly conserved pathway activated when the SHH ligand binds to its PTCH1 or PTCH2 receptors, relieving the inhibition of smoothened and activated GLI1, GLI2, and GLI3. The transcriptional factors of the GLI family in mammals, including GLI1, GLI2, and GLI3 serve important roles in the SHH signaling pathway. SHH receptor binding also prevents inhibition by the downstream negative regulators SUFU and PKA [64, 65]. 
Interestingly, the $\mathrm{SHH}$ ligand was not differentially expressed in this study. These findings suggest that there is a non-canonical upregulation of the $\mathrm{SHH}$ pathway, as reported in previous studies [66, 67]. Future studies should focus on elucidating which compounds can lead to increased expression of the GLI transcription factors in the CL. Antiapoptotic proteins such as BCL-2, MCL1 , and BCL-XL were shown to be GLI target genes [18]. These proteins were increased in CL by IFNT in vivo [15] and in LGCs in vitro [17]. Interestingly, we found here that IFNT elevated GLI2 and PTCH2 mRNA expression but not GLII and SUFU in LGCs. These findings suggest a possible role for GLI2 in the survival of luteal cells by the upregulation of anti-apoptotic proteins.

Inactivation of the MMP pathway is enriched in the $\mathrm{P}$ cow CL (Fig. 7A) compared with NP CL. MMPs and and their tissue inhibitors (TIMPs) have been implicated as key regulators in the structural involution of the CL during luteal regression [68-70]. PGF2A stimulated MMPs involved in the breakdown of ECM during luteolysis, which accelerates cell detachment from the $\mathrm{CL}$ during luteolysis $[69,70]$. THBS2, another component of the MMP pathway is upregulated in vivo and in vitro by PGF2A treatment $[35,38]$ and inhibited during the early period (this study) or for the entire pregnancy [71]. Importantly, the current study shows that IFNT directly inhibited THBS2 in LGC, along with MMP9, ADAM17, and TIMP3, genes constituting the canonical IPA pathway termed "inhibition of MMPs" These results suggest that inhibition of the MMP pathway can serve as a tool to achieve ECM stabilization during pregnancy.

\section{Conclusions}

This study unraveled the distinct molecular profile of early pregnancy $\mathrm{CL}$ on day 18 , suggesting that it differs substantially from the non-pregnant gland on the same day. Our results suggest that a wide range of functional pathways may be affected: endothelial activation is restrained, blood vessels are stabilized, apoptotic mechanisms are inhibited, steroidogenesis is maintained, and the ECM is preserved. Additionally, the similarity between the regulation of genes by IFNT in vitro and the expression of these genes in the pregnancy CL suggests that the endocrine actions of IFNT may contribute to the characteristics of early pregnancy CL.

\section{Materials and methods}

\section{Animals and samples collection}

The experiment was conducted in accordance with relevant guidelines and regulations at the Experimental Station Hildegard Georgina Von Pritzelwiltz, located in Londrina, PR, Brazil. The Animal Research Ethics Committee of Escola Superior de Agricultura "Luiz de
Queiroz" (ESALQ)/University of São Paulo approved all procedures involving cows in this study (Protocol \#2018.5.1252.11.5). Non-lactating, Bos indicus, multiparous cows $(n=35)$, were submitted to the fixed-time AI (FTAI) protocol as described by Madureira et al. [72]. On the day of insemination (Day 0), cows were assigned into the groups: artificial insemination [AI] group $(n=$ 20) or synchronized, non-inseminated group (cyclic; $n=$ 10), cows from the AI group were then inseminated using frozen/thawed semen from two high fertility Aberdeen Angus bulls (Alta Genetics, Uberaba, Brazil). On day 17 after AI and 1 day before CL collection, blood samples were collected by puncturing the coccygeal vein into evacuated $10 \mathrm{~mL}$ tubes containing sodium heparin (Vacutainer, Dickinson, Franklin Lakes, NJ, USA). Immediately after collection, the tubes were placed on ice and kept refrigerated until processing. Blood samples were centrifuged at $1700 \times \mathrm{g}$ for $15 \mathrm{~min}$ and aliquots of plasma were frozen and stored in duplicate at $-20^{\circ} \mathrm{C}$ until they were assayed for progesterone. On Day 18 all cows were slaughtered, and each uterine horn of cows in the AI group was flushed with $10 \mathrm{~mL}$ of sterile saline solution. Pregnancy was confirmed by identifying an elongated embryo in uterine flushes, ISGs expression and serum $\mathrm{P} 4$ concentration 7 cows were chosen. The presence of a functional CL was confirmed by measuring plasma progesterone using a commercial RIA kit (CT Progesterone, MP Biomedicals LLC, Solon, OH, USA), following the manufacturer's instructions as previously described and validated for bovine plasma [73]. The intra- and inter-assay CVs were 2.1 and $2.2 \%$ respectively, and the sensitivity was $0.05 \mathrm{ng} / \mathrm{mL}$. The CL were collected in cryotubes and immediately frozen in liquid nitrogen and stored at $-80^{\circ} \mathrm{C}$ for subsequent RNA extraction and determination of luteal progesterone. Approximately $20 \mathrm{mg}$ of the $\mathrm{CL}$ sample, were minced and the homogenates divided into two parts. One part was submitted to a progesterone RIA assay as described above, and the second part of the homogenate was used for protein determination (using Bicinchoninic Acid Kit, Sigma-Aldrich).

\section{RNA isolation and transcriptomics}

For next generation sequencing (NGS), total RNA was isolated from all 14 samples (7 samples for each $\mathrm{P}$ and NP groups) using the Tri-Reagent (Molecular Research Center Inc., Cincinnati, Ohio, USA) according to the manufacturer's instructions. The quantity, quality, and purity of RNA were determined using a 2100 Bioanalyzer instrument (Agilent Technologies, Waldbronn, Germany) and a NanoDrop Spectrophotometer (Thermo Fisher Scientific, Waltham, MA, USA). Only samples with an RNA integrity number (RIN) number greater 
than 7.5, with all A260/230 ratios $>2.00$, and all 260/280 ratios $>1.98$ were eligible for this study. Based on the quality and quantity of RNA further analysis were carried out with 6 cows per group. Sequencing and bioinformatics analysis were carried out at The Nancy and Stephen Grand Israel National Center for Personalized Medicine of The Weizmann Institute of Science, Israel.

\section{Sequencing}

First, $500 \mathrm{ng}$ of total RNA for each sample was processed using an in-house poly A-based RNA seq protocol [74]. Briefly, total RNA was fragmented, followed by reverse transcription and second strand cDNA synthesis. The double strand cDNA was subjected to end repair, A-base addition, adapter ligation, and PCR amplification to create libraries. Libraries were evaluated by Qubit and TapeStation. Sequencing libraries were constructed with barcodes to allow multiplexing. Single end $84 \mathrm{bp}$ reads were sequenced on an Illumina NextSeq 500 machine, yielding a median of $17 \mathrm{M}$ reads per sample. Both before and after the trimming, the median of the first bases was 32 and from base 6 the median of the quality was 36 . $92-93 \%$ of the reads had a mean quality of at least 30 , after the trimming (before the trimming, $90-93 \%$ of the reads had a mean quality of at least 30 ). Most reads had a GC content of $44-45 \%$.

\section{Bioinformatics}

Poly-A/T stretches and Illumina adapters were trimmed from the reads using cutadapt; resulting reads shorter than $30 \mathrm{bp}$ were discarded. Reads were mapped to the reference genome ARS-UCD1.2 using STAR [75], supplied with gene annotations downloaded from Ensembl (with the End-To-End option). Expression levels for each gene were quantified using htseq-count [76], using the gene transfer format (GTF) file. Differentially expressed genes were identified using DESeq2 [77] with the betaPrior, cooksCutoff, and the independent filtering parameters set to False. Raw $P$ values were adjusted for multiple testing using the procedure of Benjamini and Hochberg. The full pipeline was run using snakemake [78]. Genes were considered to be differentially expressed in $\mathrm{P}$ compared to NP, with $\log 2$ fold change $(\mathrm{FC}) \geq 0.58$ for the upregulated genes and $\leq-0.58$ for the downregulated genes with the adjusted $p$-value below 0.05 and the gene had a count of at least 30 in one sample. Functional and pathway analysis was performed on transcriptomic data using Ingenuity pathway analysis (IPA), Metascape, and GSEA. Prior to the pathway analysis, DEGs were converted into human orthologues to make use of well-established human pathway analysis databases (KEGG and Reactome).

\section{Ingenuity pathway analysis (IPA)}

IPA (Qiagen, Inc., Valencia, CA, USA) was used to identify the predicted canonical pathways, associated diseases, and functions, key upstream regulators, and the related signaling pathways (https://www. qiagenbioinformatics.com/products/ingenuity-pathwayanalysis). A list of DEGs with associated $\log 2 \mathrm{FC} \geq 0.58$ for the upregulated genes and $\leq-0.58$ for the downregulated genes with padj $\leq 0.05$ and a count of 60 at least in one of the samples, was uploaded into the IPA server (http://www.ingenuity.com; version 2.3) to identify the enriched canonical pathways. Based on the information stored in the Ingenuity Knowledge Base (IKB), genes were mapped to networks and pathways. Raw $p$ values were adjusted for multiple testing using the procedure of Benjamini and Hochberg. Pathways with $[-\log 10$ (B-H (p-value)] $>1.3$ (the equivalent of $p<0.05$ ) were considered as significantly enriched, along with an activation score (Z-score) above $\geq 1.90$.

\section{Metascape analysis}

Metascape (http://metascape.org/), a gene annotation and analysis resource [79], was used to perform a functional enrichment analysis, which included a canonical, KEGG, and reactome pathway analysis of the overlapping DEGs in all three databases. DEGs that were significantly upregulated $(\log 2 \mathrm{FC} \geq 0.58)$ genes and downregulated $(\log 2 \mathrm{FC} \leq$ -0.58 ) genes with padj $\leq 0.05$ were uploaded in a separate list in the Metascape server.

\section{Gene set enrichment analysis (GSEA)}

Whole expression data from the $\mathrm{P}$ and NP groups were subjected to gene set enrichment analysis using GSEA [80]. GSEA ranks the genes in expression dataset and then analyzes those pre-ranked genes to determine whether a priori defined sets of genes show statistically significant, concordant differences between two biological states. The differential expression data were tested against the hallmark gene set collection from the molecular signature database, MsigDB v7.2 as well as the KEGG and REACTOME databases. GSEA was applied to the human ortholog genes that were obtained by HomoloGene database and bovine Ensembl. For genes where there was more than one ortholog, one was chosen randomly.

\section{Isolation and culture of granulosa cells}

We collected bovine ovaries bearing large follicles (>10 mm in diameter) from a local slaughterhouse, as described previously $[17,81]$. Only follicles containing at least 4 million granulosa cells were included in these experiments. Granulosa cells were enzymatically dispersed and seeded for overnight incubation in DMEM/F-12 containing 3\% fetal calf 
serum (FCS). The next day, the media was replaced with luteinization media containing FCS $(1 \%)$, insulin $(2 \mu \mathrm{g} / \mathrm{mL})$, and forskolin $(10 \mu \mathrm{M})[17,81]$. Then, the cells were washed with phosphate buffered saline (PBS), and kept for a 3-5h adaptation period in DMEM/F-12 media containing $1 \%$ FCS. Finally, the cells were incubated $24-36 \mathrm{~h}$ as indicated in the results section, with either basal media (containing 1\% FCS; control) or roIFNT $(1 \mathrm{ng} / \mathrm{mL}$; a generous gift from Prof. Fuller W. Bazer, Texas A\&M University and it was functionally validated in numerous studies [9]). At the end of the incubation period, cells were collected for either total RNA extraction, as described below.

\section{RNA extraction and quantitative real-time PCR}

Total RNA was isolated using Tri-Reagent (Molecular Research Center Inc., Cincinnati, Ohio, USA) according to the manufacturer's instructions. $1 \mu \mathrm{g}$ of total RNA was reverse transcribed by using the qScript cDNA synthesis kit (Quantabio, Beverly, MA, USA). Real-time PCR was performed using the LightCycler 96 system with LightCycler 480 SYBR Green I Master (Roche Diagnostics, Indianapolis, IN, USA) $[17,82]$. The lists of sequences of primers used for quantitative qPCR were provided in Supplementary Table 1. All primers were designed to span an intron to prevent amplification of genomic DNA, and have single-product melting curves, as well as consistent amplification efficiencies between 1.8 and $2.2[17,82]$. We selected GAPDH and RPS26 as a housekeeping genes, as described previously [16, 82]. The threshold cycle number $(\mathrm{Ct})$ was used to quantify the relative abundance of the gene; arbitrary units were calculated as $2-\Delta \mathrm{Ct}=2-(\mathrm{Ct}$ target gene $-\mathrm{Ct}$ housekeeping gene $)$.

\section{Statistical analyses - cell culture}

Statistical analyses of the in vitro work were performed using GraphPad Prism version 6.01 Software (GraphPad Software, Inc., San Diego, CA). Data are presented as means \pm SEM. Cell culture experiments comprised at least four independent repeats; each repeat consisted of cells obtained from different follicles (one follicle/cow), examined in duplicates. Data were analyzed by either Student's t-test or one-way ANOVA, when indicated. In all analyses, a value of $p \leq 0.05$ was considered significant.

\section{Abbreviations}

DEGs: Differentially expressed genes; EDN1: Endothelin 1; ECM: Extracellular matrix; GSEA: Gene Set Enrichment Analysis; IPA: Ingenuity Pathway Analysis; PDGF: Platelet Derived Growth Factor; PGF2A: Prostaglandin F2 Alpha; TGFB: Transforming Growth Factor Beta; TNFA: Tumor necrosis factor alpha

\section{Supplementary Information}

The online version contains supplementary material available at https://doi. org/10.1186/s12864-021-07747-3.

Additional file 1 Supplementary Fig. 1. Principal component analysis (PCA) of P cows and NP cows samples are clustered by gene-expression profile. The analysis was based on the 1000 most variable genes. P; Pregnant cows; NP: Non-pregnant cows.

Additional file 2 Supplementary Table 1. List of primers used for qRT-PCR.

\section{Acknowledgments}

The authors thank Dr. Jose R. S. Gonçalves and the staff of Experimental Station Hildegard Georgina Von Pritzelwitz (Londrina, PR, Brazil) for the animals, facilities, and technical support. We also thank Dr. G Madureira from the University of São Paulo, Piracicaba, Brazil for the support of animal studies. We are grateful to Prof. Emmett K. Inskeep from West Virginia University for helpful discussions and to Prof. Fuller W. Bazer from Texas A\&M University for a generous gift of recombinant ovine IFNT. We thank Dr. Hadar Benyamini from the Hebrew University Bioinformatics unit (Info-CORE) for the GSEA data analysis and interpretation and Prof. Milo Wiltbank from the University of Wisconsin, Madison for assisting in the processing of the $\mathrm{CL}$ samples. G.F. is the Incumbent of the David and Stacey Cynamon Research fellow Chair in Genetics and Personalized Medicine.

\section{Authors' contributions}

$\mathrm{RB}$, and RM designed research; JND and RS collected the in vivo samples and $\mathrm{RB}$ processed the samples. RB, JS, LB and SK participated in the in vitro research; RB, GF and RM analyzed data and prepared the figures; RB, JS and RM wrote the paper; all other authors reviewed, corrected and approved the final manuscript.

\section{Funding}

This work was supported by a grant from Binational Agricultural Research \& Development Fund (BARD- IS-4799-15) and São Paulo Research Foundation (FAPESP, São Paulo, Brazil, Project 2018/03798-7). The BARD or FAPESP did not participate in any component of the study design, collection, analysis, interpretation of data or in writing the manuscript.

\section{Availability of data and materials}

The datasets generated and/or analysed during the current study are available in the GEO repository, [persistent web link to datasets: https://www. ncbi.nlm.nih.gov/geo/query/acc.cgi?acc=GSE163212].

To review GEO accession GSE163212:

Go to https://www.ncbi.nlm.nih.gov/geo/query/acc.cgi?acc=GSE163212 Enter token qjurmsqadxcxdcv into the box.

The following secure token has been created to allow review of record GSE163212 while it remains in private status.

\section{Declarations}

Ethics approval and consent to participate

The experimental procedures were approved by local experimental Station Hildegard Georgina Von Pritzelwiltz, located in Londrina, PR, Brazil. The Animal Research Ethics Committee of Escola Superior de Agricultura "Luiz de Queiroz" (ESALQ)/University of São Paulo approved all procedures involving cows in this study (Protocol \#2018.5.1252.11.5). This study was carried out in compliance with the ARRIVE guidelines (http://www.nc3rs.org.uk/page. asp?id=1357).

\section{Consent for publication}

Not applicable.

\section{Competing interests}

The authors declare that there are no financial and non-financial competing interests that could affect this research.

\section{Author details}

${ }^{1}$ Department of Animal Sciences, The Robert H. Smith Faculty of Agriculture, Food and Environment, The Hebrew University of Jerusalem, 7610001 Rehovot, Israel. Department of Animal Science, University of São Paulo, Piracicaba, Brazil. ${ }^{3}$ The Mantoux Bioinformatics institute of the Nancy and Stephen Grand Israel National Center for Personalized Medicine, Weizmann Institute of Science, Weizmann Institute of Science, 7610001 Rehovot, Israel. 
Received: 16 December 2020 Accepted: 21 May 2021 Published online: 16 June 2021

\section{References}

1. Schams D, Berisha B. Regulation of corpus luteum function in cattle--an overview. Reprod Domest Anim. 2004;39(4):241-51. https://doi.org/10.1111/ j.1439-0531.2004.00509.x

2. Niswender GD, Juengel JL, Silva PJ, Rollyson MK, Mclntush EW. Mechanisms controlling the function and life span of the corpus luteum. Physiol Rev. 2000;80(1):1-29. https://doi.org/10.1152/physrev.2000.80.1.1.

3. Rhinehart JD, Starbuck-Clemmer MJ, Flores JA, Milvae RA, Yao J, Poole DH, et al. Low peripheral progesterone and late embryonic/early fetal loss in suckled beef and lactating dairy cows. Theriogenology. 2009;71(3):480-90. https://doi.org/10.1016/j.theriogenology.2008.07.031.

4. Lonergan P. Influence of progesterone on oocyte quality and embryo development in cows. Theriogenology. 2011;76(9):1594-601. https://doi. org/10.1016/j.theriogenology.2011.06.012.

5. Dorniak P, Bazer FW, Spencer TE. Physiology and endocrinology symposium: biological role of interferon tau in endometrial function and conceptus elongation. J Anim Sci. 2013;91(4):1627-38. https://doi.org/10.2527/jas.20125845 .

6. McCracken JA, Custer EE, Lamsa JC. Luteolysis: a neuroendocrine-mediated event. Physiol Rev. 1999;79(2):263-323. https://doi.org/10.1152/physrev.1999. 79.2.263.

7. Meidan R, Girsh E, Mamluk R, Levy N. S F. Luteolysis. In: Meidan R, editor. Ruminants: past concepts, new insights, and persisting challenges. Cham: Springer International Publishing; 2017.

8. Roberts RM. Interferon-tau, a type 1 interferon involved in maternal recognition of pregnancy. Cytokine Growth Factor Rev. 2007;18(5-6):403-8. https://doi.org/10.1016/j.cytogfr.2007.06.010.

9. Bazer FW, Thatcher WW. Chronicling the discovery of interferon tau. Reproduction. 2017;154(5):F11-20. https://doi.org/10.1530/REP-17-0257.

10. Roberts RM, Cross JC, Leaman DW. Interferons as hormones of pregnancy. Endocr Rev. 1992;13(3):432-52. https://doi.org/10.1210/edrv-13-3-432.

11. Bazer FW. Mediators of maternal recognition of pregnancy in mammals. Proc Soc Exp Biol Med. 1992;199(4):373-84. https://doi.org/10.3181/0037972 7-199-43371A

12. Binelli M, Subramaniam P, Diaz T, Johnson GA, Hansen TR, Badinga L, et al. Bovine interferon-tau stimulates the Janus kinase-signal transducer and activator of transcription pathway in bovine endometrial epithelial cells. Biol Reprod. 2001;64(2):654-65. https://doi.org/10.1095/biolreprod64.2.654.

13. Chen Y, Green JA, Antoniou E, Ealy AD, Mathialagan N, Walker AM, et al. Effect of interferon-tau administration on endometrium of nonpregnant ewes: a comparison with pregnant ewes. Endocrinology. 2006;147(5):212737. https://doi.org/10.1210/en.2005-1310.

14. Oliveira JF, Henkes LE, Ashley RL, Purcell SH, Smirnova NP, Veeramachaneni $\mathrm{DN}$, et al. Expression of interferon (IFN)-stimulated genes in extrauterine tissues during early pregnancy in sheep is the consequence of endocrine IFN-tau release from the uterine vein. Endocrinology. 2008;149(3):1252-9. https://doi.org/10.1210/en.2007-0863.

15. Romero JJ, Antoniazzi AQ, Smirnova NP, Webb BT, Yu F, Davis JS, et al. Pregnancy-associated genes contribute to antiluteolytic mechanisms in ovine corpus luteum. Physiol Genomics. 2013;45(22):1095-108. https://doi. org/10.1152/physiolgenomics.00082.2013.

16. Basavaraja R, Przygrodzka E, Pawlinski B, Gajewski Z, Kaczmarek MM, Meidan R. Interferon-tau promotes luteal endothelial cell survival and inhibits specific luteolytic genes in bovine corpus luteum. Reproduction. 2017; 154(5):559-68. https://doi.org/10.1530/REP-17-0290.

17. Basavaraja R, Madusanka ST, Drum JN, Shrestha K, Farberov S, Wiltbank MC, et al. Interferon-tau exerts direct Prosurvival and Antiapoptotic actions in luteinized bovine granulosa cells. Sci Rep. 2019;9(1):14682. https://doi.org/1 0.1038/s41598-019-51152-6.

18. Yang $L$, Wang $X L$, Wan $P C$, Zhang $L Y$, Wu Y, Tang DW, et al. Up-regulation of expression of interferon-stimulated gene 15 in the bovine corpus luteum during early pregnancy. J Dairy Sci. 2010;93(3):1000-11. https://doi.org/10.31 68/jds.2009-2529.

19. Hirayama H, Moriyasu S, Kageyama S, Sawai K, Takahashi H, Geshi M, et al. Enhancement of maternal recognition of pregnancy with parthenogenetic embryos in bovine embryo transfer. Theriogenology. 2014:81(8):1108-15. https://doi.org/10.1016/j.theriogenology.2014.01.039.
20. Rashid MB, Talukder AK, Kusama K, Haneda S, Takedomi T, Yoshino H, et al. Evidence that interferon-tau secreted from Day-7 embryo in vivo generates anti-inflammatory immune response in the bovine uterus. Biochem Biophys Res Commun. 2018;500(4):879-84. https://doi.org/10.1016/j.bbrc.2018.04.178.

21. Mann GE, Lamming GE, Robinson RS, Wathes DC. The regulation of interferon-tau production and uterine hormone receptors during early pregnancy. J Reprod Fertil Suppl. 1999;54:317-28.

22. Spencer TE, Bazer FW. Ovine interferon tau suppresses transcription of the estrogen receptor and oxytocin receptor genes in the ovine endometrium. Endocrinology. 1996;137(3):1144-7. https://doi.org/10.1210/endo.137.3.8603 586.

23. Hansen TR, Sinedino LDP, Spencer TE. Paracrine and endocrine actions of interferon tau (IFNT). Reproduction. 2017;154(5):F45-59. https://doi.org/10.1 530/REP-17-0315.

24. Romero JJ, Antoniazzi AQ, Nett TM, Ashley RL, Webb BT, Smirnova NP, et al. Temporal release, paracrine and endocrine actions of ovine conceptusderived interferon-tau during early pregnancy. Biol Reprod. 2015;93(6):146. https://doi.org/10.1095/biolreprod.115.132860.

25. Bott RC, Ashley RL, Henkes LE, Antoniazzi AQ, Bruemmer JE, Niswender GD, et al. Uterine vein infusion of interferon tau (IFNT) extends luteal life span in ewes. Biol Reprod. 2010;82(4):725-35. https://doi.org/10.1095/biolreprod.109. 079467

26. Antoniazzi AQ, Webb BT, Romero JJ, Ashley RL, Smirnova NP, Henkes LE, et al. Endocrine delivery of interferon tau protects the corpus luteum from prostaglandin F2 alpha-induced luteolysis in ewes. Biol Reprod. 2013;88(6): 144. https://doi.org/10.1095/biolreprod.112.105684.

27. Basavaraja R, Madusanka ST, Shrestha K, Przygrodzka E, Kaczmarek MM, Meidan R. Pentraxin-3 mediates prosurvival actions of interferon tau in bovine luteinized granulosa cells. Reproduction. 2020;160(4):603-12. https:// doi.org/10.1530/REP-20-0200.

28. Hughes CHK, Inskeep EK, Pate JL. Temporal changes in the corpus luteum during early pregnancy reveal regulation of pathways that enhance steroidogenesis and suppress luteolytic mechanismsdagger. Biol Reprod. 2020;103(1):70-84. https://doi.org/10.1093/biolre/ioaa047.

29. Hughes CK, Maalouf SW, Liu WS, Pate JL. Molecular profiling demonstrates modulation of immune cell function and matrix remodeling during luteal rescuedagger. Biol Reprod. 2019;100(6):1581-96. https://doi.org/10.1093/biolre/ioz037.

30. Pokharel K, Peippo J, Weldenegodguad M, Honkatukia M, Li MH, Kantanen J. Gene Expression Profiling of Corpus luteum Reveals Important Insights about Early Pregnancy in Domestic Sheep. Genes (Basel). 2020;11(4).

31. Li X, Long J, He T, Belshaw R, Scott J. Integrated genomic approaches identify major pathways and upstream regulators in late onset Alzheimer's disease. Sci Rep. 2015:5(1):12393. https://doi.org/10.1038/srep12393.

32. Matsuyama S, Kojima T, Kato S, Kimura K. Relationship between quantity of IFNT estimated by IFN-stimulated gene expression in peripheral blood mononuclear cells and bovine embryonic mortality after Al or ET. Reprod Biol Endocrinol. 2012;10(1):21. https://doi.org/10.1186/1477-7827-10-21.

33. Shirasuna K, Matsumoto H, Kobayashi E, Nitta A, Haneda S, Matsui M, et al. Upregulation of interferon-stimulated genes and interleukin-10 in peripheral blood immune cells during early pregnancy in dairy cows. J Reprod Dev. 2012;58(1):84-90. https://doi.org/10.1262/jrd.11-094K.

34. Hou X, Arvisais EW, Jiang C, Chen DB, Roy SK, Pate JL, et al. Prostaglandin F2alpha stimulates the expression and secretion of transforming growth factor B1 via induction of the early growth response 1 gene (EGR1) in the bovine corpus luteum. Mol Endocrinol. 2008;22(2):403-14. https://doi.org/1 0.1210/me.2007-0272.

35. Mondal M, Schilling B, Folger J, Steibel JP, Buchnick H, Zalman Y, et al. Deciphering the luteal transcriptome: potential mechanisms mediating stage-specific luteolytic response of the corpus luteum to prostaglandin F(2)alpha. Physiol Genomics. 2011;43(8):447-56. https://doi.org/10.1152/ physiolgenomics.00155.2010.

36. Shah KB, Tripathy S, Suganthi H, Rudraiah M. Profiling of luteal transcriptome during prostaglandin F2-alpha treatment in buffalo cows: analysis of signaling pathways associated with luteolysis. PLoS One. 2014; 9(8):e104127. https://doi.org/10.1371/journal.pone.0104127.

37. Talbott H, Hou X, Qiu F, Zhang P, Guda C, Yu F, et al. Early transcriptome responses of the bovine midcycle corpus luteum to prostaglandin F2alpha includes cytokine signaling. Mol Cell Endocrinol. 2017;452:93-109. https:// doi.org/10.1016/j.mce.2017.05.018.

38. Zalman Y, Klipper E, Farberov S, Mondal M, Wee G, Folger JK, et al. Regulation of angiogenesis-related prostaglandin f2alpha-induced genes in 
the bovine corpus luteum. Biol Reprod. 2012;86(3):92. https://doi.org/10.1 095/biolreprod.111.095067.

39. Levy N, Kobayashi S, Roth Z, Wolfenson D, Miyamoto A, Meidan R. Administration of prostaglandin $\mathrm{f}(2$ alpha) during the early bovine luteal phase does not alter the expression of ET-1 and of its type a receptor: a possible cause for corpus luteum refractoriness. Biol Reprod. 2000;63(2):37782. https://doi.org/10.1095/biolreprod63.2.377.

40. Pinaffi FLV, Araujo ER, Ginther OJ. Concentrations of a PGF2alpha metabolite during pregnancy on the days that luteolysis occurs in nonbred heifers. Domest Anim Endocrinol. 2018;62:76-82. https://doi.org/10.1016/j.doma niend.2017.10.002.

41. Inskeep EK, Smutny WJ, Butcher RL, Pexton JE. Effects of intrafollicular injections of prostaglandins in non-pregnant and pregnant ewes. J Anim Sci. 1975;41(4):1098-104. https://doi.org/10.2527/jas1975.4141098x.

42. Nancarrow CD, Evison BM, Connell PJ. Effect of embryos on luteolysis and termination of early pregnancy in sheep with cloprostenol. Biol Reprod. 1982;26(2):263-9. https://doi.org/10.1095/biolreprod26.2.263.

43. Silvia WJ, Niswender GD. Maintenance of the corpus luteum of early pregnancy in the ewe. IV. Changes in luteal sensitivity to prostaglandin F2 alpha throughout early pregnancy. J Anim Sci. 1986;63(4):1201-7. https:// doi.org/10.2527/jas1986.6341201x

44. Silvia WJ, Niswender GD. Maintenance of the corpus luteum of early pregnancy in the ewe. III. Differences between pregnant and nonpregnant ewes in luteal responsiveness to prostaglandin F2 alpha. J Anim Sci. 1984; 59(3):746-53. https://doi.org/10.2527/jas1984.593746x.

45. Arosh JA, Banu SK, McCracken JA. Novel concepts on the role of prostaglandins on luteal maintenance and maternal recognition and establishment of pregnancy in ruminants. J Dairy Sci. 2016;99(7):5926-40. https://doi.org/10.3168/jds.2015-10335.

46. Lee J, Banu SK, McCracken JA, Arosh JA. Early pregnancy modulates survival and apoptosis pathways in the corpus luteum in sheep. Reproduction. 2016; 151(3):187-202. https://doi.org/10.1530/REP-15-0302.

47. Wilson L Jr, Butcher RL, Inskeep EK. Prostaglandin F2alpha in the uterus of ewes during early pregnancy. Prostaglandins. 1972;1 (6):479-82. https://doi. org/10.1016/0090-6980(72)90017-2.

48. Zarco L, Stabenfeldt GH, Basu S, Bradford GE, Kindahl H. Modification of prostaglandin F-2 alpha synthesis and release in the ewe during the initial establishment of pregnancy. J Reprod Fertil. 1988;83(2):527-36. https://doi. org/10.1530/jf.0.0830527.

49. Mezera MA, Hamm CS, Gamarra CA, Gennari RS, Prata AB, Sartori R, et al. Profiles of prostaglandin F2alpha metabolite in dairy cattle during luteal regression and pregnancy: implications for corpus luteum maintenancedagger. Biol Reprod. 2019;101 (1):76-90. https://doi.org/10.1093/biolre/ioz074.

50. Banu SK, Lee J, Stephen SD, Nithy TK, Arosh JA. Interferon tau regulates PGF2alpha release from the ovine endometrial epithelial cells via activation of novel JAK/EGFR/ERK/EGR-1 pathways. Mol Endocrinol. 2010;24(12):231530. https://doi.org/10.1210/me.2010-0205.

51. Farberov S, Meidan R. Thrombospondin-1 affects bovine luteal function via transforming growth factor-Beta1-dependent and independent actions. Biol Reprod. 2016;94(1):25. https://doi.org/10.1095/biolreprod.115.135822.

52. Farberov $S$, Meidan R. Functions and transcriptional regulation of thrombospondins and their interrelationship with fibroblast growth factor-2 in bovine luteal cells. Biol Reprod. 2014;91(3):58. https://doi.org/10.1095/ biolreprod.114.121020

53. Maroni D, Davis JS. TGFB1 disrupts the angiogenic potential of microvascular endothelial cells of the corpus luteum. J Cell Sci. 2011;124(Pt 14):2501-10. https://doi.org/10.1242/jcs.084558.

54. Farberov S, Basavaraja R, Meidan R. Thrombospondin-1 at the crossroads of corpus luteum fate decisions. Reproduction. 2018.

55. Pascuali N, Scotti L, Abramovich D, Irusta G, Di Pietro M, Bas D, et al. Inhibition of platelet-derived growth factor (PDGF) receptor affects follicular development and ovarian proliferation, apoptosis and angiogenesis in prepubertal eCG-treated rats. Mol Cell Endocrinol. 2015;412:148-58. https:// doi.org/10.1016/j.mce.2015.04.021

56. Woad KJ, Hammond AJ, Hunter M, Mann GE, Hunter MG, Robinson RS. FGF2 is crucial for the development of bovine luteal endothelial networks in vitro. Reproduction. 2009;138(3):581-8. https://doi.org/10.1530/REP-09-0030.

57. Girsh E, Milvae RA, Wang W, Meidan R. Effect of endothelin-1 on bovine luteal cell function: role in prostaglandin F2alpha-induced antisteroidogenic action. Endocrinology. 1996;137(4):1306-12. https://doi.org/10.1210/endo.13 7.4.8625904
58. Ohtani M, Kobayashi S, Miyamoto A, Hayashi K, Fukui Y. Real-time relationships between intraluteal and plasma concentrations of endothelin, oxytocin, and progesterone during prostaglandin F2alpha-induced luteolysis in the cow. Biol Reprod. 1998;58(1):103-8. https://doi.org/10.1095/ biolreprod58.1.103.

59. Costine BA, Inskeep EK, Blemings KP, Flores JA, Wilson ME. Mechanisms of reduced luteal sensitivity to prostaglandin F2alpha during maternal recognition of pregnancy in ewes. Domest Anim Endocrinol. 2007;32(2): 106-21. https://doi.org/10.1016/j.domaniend.2006.01.003.

60. Przygrodzka E, Kaczmarek MM, Kaczynski P, Ziecik AJ. Steroid hormones, prostanoids, and angiogenic systems during rescue of the corpus luteum in pigs. Reproduction. 2016;151(2):135-47. https://doi.org/10.1530/REP-15-0332.

61. Hayashi K, Miyamoto A. Angiotensin II interacts with prostaglandin F2alpha and endothelin-1 as a local luteolytic factor in the bovine corpus luteum in vitro. Biol Reprod. 1999;60(5):1104-9. https://doi.org/10.1095/biolreprod60. 5.1104 .

62. Lee J, McCracken JA, Stanley JA, Nithy TK, Banu SK, Arosh JA. Intraluteal prostaglandin biosynthesis and signaling are selectively directed towards PGF2alpha during luteolysis but towards PGE2 during the establishment of pregnancy in sheep. Biol Reprod. 2012;87(4):97. https://doi.org/10.1095/ biolreprod.112.100438.

63. Silvia WJ, Ottobre JS, Inskeep EK. Concentrations of prostaglandins E2, F2 alpha and 6-keto-prostaglandin F1 alpha in the utero-ovarian venous plasma of nonpregnant and early pregnant ewes. Biol Reprod. 1984;30(4): 936-44. https://doi.org/10.1095/biolreprod30.4.936.

64. Merchant M, Vajdos FF, Ultsch M, Maun HR, Wendt U, Cannon J, et al. Suppressor of fused regulates Gli activity through a dual binding mechanism. Mol Cell Biol. 2004;24(19):8627-41. https://doi.org/10.1128/ MCB.24.19.8627-8641.2004.

65. Hui K, Arnot M, Shin HS, Sun HS, Feng ZP. Differential regulation of low and high voltage-activated calcium channels in neonatal rat myocytes following chronic PKA modulation. Channels (Austin). 2011;5(4):357-66. https://doi. org/10.4161/chan.5.4.17121.

66. Pietrobono S, Gagliardi S, Stecca B. Non-canonical hedgehog signaling pathway in Cancer: activation of GLI transcription factors beyond smoothened. Front Genet. 2019;10:556. https://doi.org/10.3389/fgene.2019. 00556.

67. Kogerman P, Grimm T, Kogerman L, Krause D, Unden AB, Sandstedt B, et al. Mammalian suppressor-of-fused modulates nuclear-cytoplasmic shuttling of Gli-1. Nat Cell Biol. 1999;1(5):312-9. https://doi.org/10.1038/13031.

68. Smith MF, McIntush EW, Ricke WA, Kojima FN, Smith GW. Regulation of ovarian extracellular matrix remodelling by metalloproteinases and their tissue inhibitors: effects on follicular development, ovulation and luteal function. J Reprod Fertil Suppl. 1999;54:367-81.

69. Abe H, Sakumoto R, Okuda K. Expression of matrix metalloproteinases in bovine luteal cells induced by prostaglandin F2alpha, interferon gamma and tumor necrosis factor alpha. J Reprod Dev. 2015;61(4):277-86. https:// doi.org/10.1262/jrd.2014-150

70. Kliem H, Welter H, Kraetzl WD, Steffl M, Meyer HH, Schams D, et al. Expression and localisation of extracellular matrix degrading proteases and their inhibitors during the oestrous cycle and after induced luteolysis in the bovine corpus luteum. Reproduction. 2007;134(3):535-47. https://doi.org/1 0.1530/REP-06-0172.

71. Berisha B, Schams D, Rodler D, Sinowatz F, Pfaffl MW. Expression and localization of members of the thrombospondin family during final follicle maturation and corpus luteum formation and function in the bovine ovary. J Reprod Dev. 2016;62(5):501-10. https://doi.org/10.1262/jrd.2016-056.

72. Madureira G, Consentini CEC, Motta JCL, Drum JN, Prata AB, Monteiro PLJ Jr, et al. Progesterone-based timed Al protocols for Bos indicus cattle II: reproductive outcomes of either EB or GnRH-type protocol, using or not GnRH at Al. Theriogenology. 2020;145:86-93. https://doi.org/10.1016/j. theriogenology.2020.01.033.

73. Melo LF, Monteiro PLJ Jr, Oliveira LH, Guardieiro MM, Drum JN, Wiltbank $M C$, et al. Circulating progesterone concentrations in nonlactating Holstein cows during reuse of intravaginal progesterone implants sanitized by autoclave or chemical disinfection. J Dairy Sci. 2018;101(4):3537-44. https:// doi.org/10.3168/jds.2017-13569.

74. Bossel Ben-Moshe N, Gilad S, Perry G, Benjamin S, Balint-Lahat N, Pavlovsky A, et al. mRNA-seq whole transcriptome profiling of fresh frozen versus archived fixed tissues. BMC Genomics. 2018;19(1):419. https://doi.org/10.11 86/s12864-018-4761-3. 
75. Dobin A, Davis CA, Schlesinger F, Drenkow J, Zaleski C, Jha S, et al. STAR: ultrafast universal RNA-seq aligner. Bioinformatics. 2013;29(1):15-21. https:// doi.org/10.1093/bioinformatics/bts635.

76. Anders S, Pyl PT, Huber W. HTSeq--a Python framework to work with highthroughput sequencing data. Bioinformatics. 2015;31(2):166-9. https://doi. org/10.1093/bioinformatics/btu638.

77. Love Ml, Huber W, Anders S. Moderated estimation of fold change and dispersion for RNA-seq data with DESeq2. Genome Biol. 2014;15(12):550. https://doi.org/10.1186/s13059-014-0550-8

78. Koster J, Rahmann S. Snakemake-a scalable bioinformatics workflow engine. Bioinformatics. 2018;34(20):3600. https://doi.org/10.1093/bioinformatics/bty3 50.

79. Zhou Y, Zhou B, Pache L, Chang M, Khodabakhshi AH, Tanaseichuk O, et al. Metascape provides a biologist-oriented resource for the analysis of systems-level datasets. Nat Commun. 2019;10(1):1523. https://doi.org/10.103 8/s41467-019-09234-6.

80. Subramanian A, Tamayo P, Mootha VK, Mukherjee S, Ebert BL, Gillette MA, et al. Gene set enrichment analysis: a knowledge-based approach for interpreting genome-wide expression profiles. Proc Natl Acad Sci U S A. 2005;102(43):15545-50. https://doi.org/10.1073/pnas.0506580102.

81. Meidan R, Girsh E, Blum O, Aberdam E. In vitro differentiation of bovine theca and granulosa cells into small and large luteal-like cells: morphological and functional characteristics. Biol Reprod. 1990;43(6):913-21. https://doi.org/10.1095/biolreprod43.6.913

82. Shrestha K, Meidan R. The CAMP-EPAC pathway mediates PGE2-induced FGF2 in bovine granulosa cells. Endocrinology. 2018;159(10):3482-91. https://doi.org/10.1210/en.2018-00527.

\section{Publisher's Note}

Springer Nature remains neutral with regard to jurisdictional claims in published maps and institutional affiliations.

Ready to submit your research? Choose BMC and benefit from:

- fast, convenient online submission

- thorough peer review by experienced researchers in your field

- rapid publication on acceptance

- support for research data, including large and complex data types

- gold Open Access which fosters wider collaboration and increased citations

- maximum visibility for your research: over $100 \mathrm{M}$ website views per year

At BMC, research is always in progress.

Learn more biomedcentral.com/submissions 